\title{
Antiviral activity of phenanthrenes from the medicinal plant Bletilla striata against influenza A virus
}

Ya Shi', Bing Zhang ${ }^{1}$, Yiyu Lu² ${ }^{2}$ Chaodong Qian ${ }^{3}$, Yan Feng ${ }^{2}$, Liwei Fang ${ }^{4}$, Zhishan Ding $^{1}$ and Dongqing Cheng ${ }^{1 *}$

\begin{abstract}
Background: Influenza represents a serious public health concern. The emergence of resistance to anti-influenza drugs underlines the need to develop new drugs. This study aimed to evaluate the anti-influenza viral activity and possible mechanisms of 12 phenanthrenes from the medicinal plant Bletilla striata (Orchidaceae family).

Methods: Twelve phenanthrenes were isolated and identified from B. striata. Influenza virus A/Sydney/5/97 (H3N2) propagated in embryonated chicken eggs was used. Phenanthrenes mixed with the virus were incubated at $37^{\circ} \mathrm{C}$ for $1 \mathrm{~h}$ and then inoculated into 9-day-old embryonated chicken eggs via the allantoic route to survey the antiviral activity in vivo. A (3-(4,5-dimethylthiazol-2-yl)-5-(3-carboxymethoxyphenyl)-2-(4-sulfophenyl)-2H-tetrazolium) (MTS)based assay was performed to evaluate the reduction of cytopathic effect induced by H3N2 on Madin-Darby canine kidney (MDCK) cells. The hemagglutination inhibition assay was used to study the blockage of virus receptors by the phenanthrenes, and the neuraminidase (NA) inhibition assay to evaluate the effects of the release of virus. The synthesis of influenza viral matrix protein mRNA in response to compound treatment was measured by real-time polymerase chain reaction.
\end{abstract}

Results: This study showed that phenanthrenes $1,2,3,4,6,9,10,11$, and 12 significantly inhibited the viruses in vivo, with inhibition rates of 20.7, 79.3, 17.2, 34.5, 34.5, 34.5, 44.8, 75.9, and 34.5\%, respectively. In MDCK models, the phenanthrenes did not show significant antiviral activity when administered as pretreatment, while phenanthrenes 2, 3, $4,6,710$, and 11 exhibited inhibitory activities as simultaneous treatment with 50\% inhibition concentration $\left(\mathrm{IC}_{50}\right)$ ranging from $14.6 \pm 2.4$ to $43.3 \pm 5.3 \mu \mathrm{M}$. The $\mathrm{IC}_{50}$ ranged from $18.4 \pm 3.1$ to $42.3 \pm 3.9 \mu \mathrm{M}$ in the post-treatment assays. Compounds 1, 3, 4, 6, 10, and 11 exhibited an inhibitory effect on NA; and compounds 2, 3, 46, 7, 10, and 11 resulted in the reduced transcription of virus matrix protein mRNA. However, no compound could inhibit hemagglutination by the influenza virus.

Conclusion: Phenanthrenes from B. striata had strong anti-influenza viral activity in both embryonated eggs and MDCK models, and diphenanthrenes seemed to have stronger inhibition activity compared with monophenanthrenes.

Keywords: Bletilla striata, Embryonated, Influenza A virus, Phenanthrene

\footnotetext{
*Correspondence: B2006069@163.com

${ }^{1}$ College of Medical Technology, Zhejiang Chinese Medical University,

Hangzhou, Zhejiang 310053, China

Full list of author information is available at the end of the article
} International License (http://creativecommons.org/licenses/by/4.0/), which permits unrestricted use, distribution, and reproduction in any medium, provided you give appropriate credit to the original author(s) and the source, provide a link to the Creative Commons license, and indicate if changes were made. The Creative Commons Public Domain Dedication waiver (http://creativecommons.org/publicdomain/zero/1.0/) applies to the data made available in this article, unless otherwise stated. 


\section{Background}

Influenza viruses are responsible for seasonal epidemics and occasional pandemics, which cause significant morbidity and mortality. The vaccines need to be reformulated almost every year owing to antigenic drift, and the timely production of pandemic vaccines remains problematic because of the limitations of current technology [1-4]. Antiviral drugs play a significant role in controlling the spread of the disease, but the emergence of drug-resistant viral strains has been reported occasionally $[5,6]$, which has become a serious public health concern globally. Therefore, safe and effective new antiviral drugs need to be developed urgently to combat viral infections for either therapeutic or prophylactic purposes.

Two surface glycoproteins are present on the envelope of the influenza virus: hemagglutinin (HA) and neuraminidase (NA). The life cycle of the influenza virus begins with viral HA binding to sialic acid (SA) receptors on the host cell surface, followed by internalization of the virus by receptor-mediated endocytosis $[7,8]$. Subsequently, endosomal acidification alters the conformation of $\mathrm{HA}$ and leads to the fusion of the host and viral membranes, which allows the release of the viral nucleoproteins (NPs) into the cytoplasm. In the nucleus of the infected cells, the viral RNAs are transcribed into mRNAs and replicated. Finally, the newly synthesized viral ribonucleoproteins (vRNPs) are exported into the cytoplasm, and after packaging, mature virions are released from the cell surface depending on the cleaving of SA receptors by sialidase. Therefore, HA plays a key role in initiating viral infection by binding to SA-containing receptors on the host cells, thus mediating the subsequent viral entry and membrane fusion [9-11]. The NA cleaves the specific linkage of the SA receptor, resulting in the release of the newly formed virions from the infected cells [12, 13]. Oseltamivir, marketed under the trade name Tamiflu, was the first orally administered commercially developed NA inhibitor. It was discovered using shikimic acid as a starting point for synthesis. Shikimic acid was originally available as an extract of Chinese star anise. Oseltamivir is on the World Health Organization's list of essential medicines, a list of the most important medications needed in a basic health system. However, it was found that a substantial number of patients might become oseltamivir-resistant as a result of oseltamivir use and that oseltamivir resistance might be significantly associated with pneumonia [14, 15].

The tuber of Bletilla striata (Orchidaceae family) is a well-known traditional Chinese herb (known as Baiji in Chinese). The Chinese Pharmacopoeia states that B. striata supports hemostasis and detumescence and promotes recovery. Phytochemical research revealed that Bletilla contains polysaccharides, bibenzyl, phenanthrene, dihydrophenanthrene, flavonoids, and phenolic compounds [16-19]. In addition, it was reported to have antimicrobial [20], antioxidant [20], and anti-inflammatory activities [21]. The chemical components of B. striata and its 2,2diphenyl-1-picrylhydrazyl (DPPH) radical-scavenging, ferric-reducing antioxidant, and tyrosinase-inhibitory activities were studied [22]. Furthermore, six biphenanthrenes were separated, and their antibacterial activities were reported [23]. In the present study, the anti-influenza viral activity of 12 phenanthrenes was investigated, and the antiviral mechanisms, such as inhibition of the activity of NA or HA, were explored.

\section{Methods}

\section{Preparation of the compounds}

The rhizomes of $B$. striata (Orchidaceae family) were collected from Tuankou Town, Zhejiang Province, People's Republic of China, and authenticated by Prof. ZS Ding (one of the authors). A voucher specimen was deposited at the Zhejiang Chinese Medical University with specimen number BS-2012-I. The organic extract of B. striata was prepared via maceration in $95 \%$ ethanol under reflux four times (each time, $100 \mathrm{~min}$ ). After removal of the solvent under reduced pressure, the residual was suspended in $1 \mathrm{~L}$ of $\mathrm{H}_{2} \mathrm{O}$ and partitioned with EtOAc $(1 \mathrm{~L} \times 4)$ to yield an EtOAc-soluble fraction. The fraction was purified on a silica gel column eluted with a gradient $\mathrm{CHCl} 3-\mathrm{MeOH}$ solvent system (100:1, 75:1, 50:1, 25:1, 5:1, and 1:1) and then purified using a high-performance liquid chromatography (HPLC) system (260 nm, $1 \mathrm{~mL} / \mathrm{min})$ on a Venusil XBP C18 column (Bonna-Agela, USA) $\left(250 \times 10 \mathrm{~mm}^{2}\right.$, $5 \mu \mathrm{M})$ eluted with a gradient mixture of acetonitrile in water with $0.1 \%$ formic acid [22, 23]. The structures were determined using an extensive spectroscopic analysis including UV, LC-MS, $1 \mathrm{H}-\mathrm{NMR}$, and 13C-NMR.

\section{Virus propagation and titration}

The influenza virus strain A/Sydney/5/97 (H3N2) used in this study was obtained from Zhejiang Provincial Center for Disease Control and Prevention, propagated in the allantoic cavity of 9- to 11-dayold chicken eggs at $34{ }^{\circ} \mathrm{C}$, and harvested $48 \mathrm{~h}$ after inoculation as the pooled allantoic fluid [24, 25]. After a brief centrifugation $\left(3000 \mathrm{rpm}\right.$ at $4{ }^{\circ} \mathrm{C}$ for $20 \mathrm{~min}$ ) and hemagglutination titer measured by a hemagglutination test (WHO, 2002), the virulence of the virus was determined by a $50 \%$ egg infective dose $\left(E_{50}\right)$ analysis in chicken eggs $[24,26]$ and a $50 \%$ tissue culture infective dose $\left(\mathrm{TCID}_{50}\right)$ analysis in Madin-Darby canine kidney (MDCK) epithelial cells $[26,27]$. 
A series of tenfold dilutions of the virus were inoculated into the chick allantoic cavity $(0.2 \mathrm{~mL} / \mathrm{embryo})$, each dilution with 10 embryos, at $34{ }^{\circ} \mathrm{C}$ for $48 \mathrm{~h}$, and then harvested. A hemagglutination test was performed, and the positive rate of each dilution was recorded. EID 50 was evaluated using the method of Reed and Muench [24, 26]. Approximately $5 \times 10^{4}$ cells/well were seeded in 96-well microplates in minimum essential medium (MEM) with $10 \%$ fetal bovine serum (FBS) at $37{ }^{\circ} \mathrm{C}$ in a humidified $5 \% \mathrm{CO}_{2}$ incubator. When the monolayer was confluent, the cells were washed twice with phosphate-buffered saline (PBS) and then infected with a series of tenfold virus dilutions (no-virus used as a control and each dilution with 10 replicates). The maintenance medium (MEM containing $100 \mathrm{U} / \mathrm{mL}$ penicillin $\mathrm{G}$ and $100 \mu \mathrm{g} / \mathrm{mL}$ streptomycin) was supplemented with $10 \mu \mathrm{g} / \mathrm{mL}$ L-1-(tosyl-amido-2-phenyl) ethyl chloromethyl ketone-treated trypsin (Sigma-Aldrich Company Ltd, UK) and then incubated at $37{ }^{\circ} \mathrm{C}$ with $5 \% \mathrm{CO}_{2}$. The development of cytopathic effect (CPE) in the host cells was observed daily until no further CPE was observed and all no-virus control cells remained normal. CPE was recorded as five grades: ++ $++(75-100 \%$ rounding of cells, increased refractility, or loss of adherence/detachment); +++ (50-74\%); ++ (25$49 \%) ;+(1-24 \%) ;-($ no morphologic changes in all the cells) (Fig. 1). The $\mathrm{TCID}_{50}$ was evaluated using the method of Reed and Muench [26, 27].

\section{Antiviral activity in embryonated eggs}

Various concentrations of the compounds were prepared by diluting with PBS and mixed with equal volumes of influenza virus at $100 \mathrm{EID}_{50}$. The compound-virus mixture was incubated for $1 \mathrm{~h}$ at $37{ }^{\circ} \mathrm{C}$. The 9-day-old swabbed eggs were punched and inoculated with the compound-virus mixture via the allantoic route. PBS and the virus without treatment were used as controls. The positive control was oseltamivir phosphate. Triplicate tests were performed for each compound against the virus. The eggs were incubated at $34{ }^{\circ} \mathrm{C}$ for $48 \mathrm{~h}$. The allantoic fluid was harvested, and the virus titer was measured using a hemagglutination test. The logarithmic transformation ( $\log 2$ calculations) was done for HA titers of the influenza virus, and the inhibitory activity was calculated. Inhibition $(\%)=(\mathrm{X}-\mathrm{Y}) / \mathrm{X} \times 100 \%$, where $\mathrm{X}$ is the $\log 2 \mathrm{HA}$ titer of the viral control, and $\mathrm{Y}$ is the $\log 2 \mathrm{HA}$ titer of the tested samples [24, 25].

\section{Cytotoxicity to MDCK cells}

An MTS-based assay was performed to evaluate the cytotoxic effects of the test compounds on MDCK cells. Approximately $5 \times 10^{4}$ cells/well were seeded in 96-well microplates in MEM with $10 \% \mathrm{FBS}$ at $37^{\circ} \mathrm{C}$ in a humidified $5 \% \mathrm{CO}_{2}$ incubator. When the monolayer was confluent, the cells were washed twice with PBS and then treated with compounds diluted in serum-
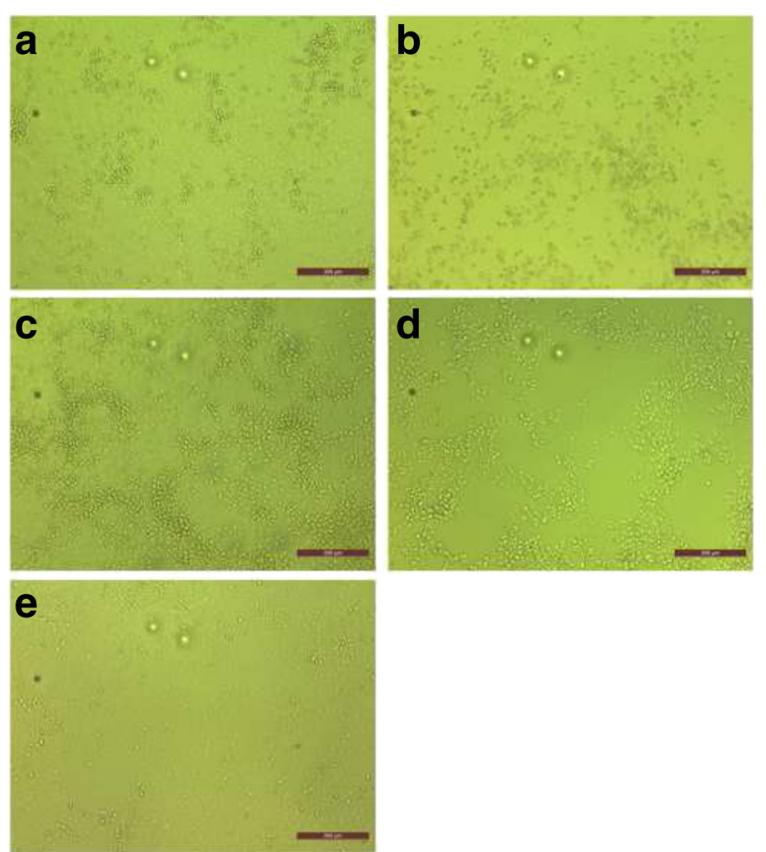

Fig. $1 \mathrm{HPLC}$ and LC-MS analyses of the compounds isolated from Bletilla striata. a HPLC fingerprint chromatogram of the 12 phenanthrenes isolated from Bletilla striata. b Total ion current chromatogram of the 12 phenanthrenes isolated from Bletilla striata, in the negative ion mode LC-MS. c Total ion current of chromatogram of the 12 phenanthrenes isolated from Bletilla striata, in the positive ion LC-MS 
free MEM. After incubation at $37^{\circ} \mathrm{C}$ for $48 \mathrm{~h}, 20 \mu \mathrm{L}$ of MTS was added to each well, and the cells were incubated for $2 \mathrm{~h}$. The absorbance at $490 \mathrm{~nm}$ was determined using a microplate reader. The cell viability was calculated using the following formula: cell viability $(\%)=($ drug treatment - background $) /($ control - background) $\times 100 \%$. The half-maximal cytotoxic concentration $\left(\mathrm{CC}_{50}\right)$ of the compounds was defined as the concentration that reduced the $\mathrm{A}_{490}$ of compoundtreated cells to $50 \%$ of that of untreated cells $[27,28]$.

\section{Reduction of CPE in MDCK cells}

Three tests were developed, and the non-cytotoxic concentration of each compound was determined using the cytotoxicity test. (1) Pretreatment: non-cytotoxic concentrations of the compounds were added to the cells, incubated for $18 \mathrm{~h}$, and then removed. The cells were washed and infected with the influenza A/Sydney/5/97 (H3N2) at $100 \mathrm{TCID}_{50}$ for $1 \mathrm{~h}$. The virus was removed, and the medium was replaced with serum-free MEM as the maintenance medium. (2) Simultaneous treatment: non-cytotoxic concentration of the compounds and the virus at $100 \mathrm{TCID}_{50}$ were added to the cell monolayers simultaneously at $37^{\circ} \mathrm{C}$ for $1 \mathrm{~h}$, and then supplemented with the maintenance medium. (3) Post-treatment: MDCK cells were infected with the virus at $37{ }^{\circ} \mathrm{C}$ for $1 \mathrm{~h}$. Then the test compounds were added for $1 \mathrm{~h}$ and then supplemented with the maintenance medium. Cells without any treatment were used as not-infected control. PBS instead of the compounds was used as the infected control and oseltamivir phosphate as the positive control. Each test was performed in triplicate. All cultures were incubated for $72 \mathrm{~h}$ at $37{ }^{\circ} \mathrm{C}$ under $5 \%$ $\mathrm{CO}_{2}$ atmosphere until the infected control showed complete CPE: almost $100 \%$ of the cells were affected and most of the cell sheet came off the wall of the culture well as observed under a light microscope [25]. Then, $20 \mu \mathrm{L}$ of MTS was added to each well, and the cells were incubated for $2 \mathrm{~h}$. The absorbance at $490 \mathrm{~nm}$ was determined using a microplate reader. CPE Inhibition $(\%)=\left(A_{\text {drug treatment }}-A_{\text {infected control }}\right) /\left(A_{\text {not-infected }}\right.$ control $-A_{\text {infected control })} \times 100 \%$. The $50 \%$ inhibition concentration (IC50) was calculated using the ReedMuench analysis [26-28].

\section{Hemagglutination inhibition assay}

The hemagglutination inhibition assay was used to study whether the compound could block the SAcontaining receptors. The phenanthrenes from B. striata and oseltamivir phosphate were all tested Fresh guinea pig blood was collected at the Laboratory Animal Research Center of the Zhejiang Chinese Medical University, supplemented with $1.6 \%$ sodium citrate in sterile water. Then, red blood cells (RBC) were separated by centrifugation $(800 \times g$ for $10 \mathrm{~min}$ at room temperature), washed three times with sterile PBS, and then suspended at a concentration of $1.5 \%$. The least number of virus particles able to agglutinate the guinea pig $R B C$ was determined in a serial virus dilution as four hemagglutination units (HAU). PBS instead of the compounds was used as the hemagglutinating positive control and no-virus RBC as the hemagglutinating negative control. Then, $50 \mu \mathrm{L}$ of the compounds in serial twofold dilutions in PBS were mixed with $50 \mu \mathrm{L}$ of $4 \mathrm{HAU}$ influenza virus suspension, incubated for $1 \mathrm{~h}$ at $37{ }^{\circ} \mathrm{C}$, mixed with an equal volume of $1.5 \%$ guinea pig RBC suspension for $1 \mathrm{~h}$ at room temperature, and then monitored for agglutination $[10,11]$.

\section{Neuraminidase inhibition assay}

The neuraminidase inhibition assay was used to evaluate the effects of each compound on the neuraminidase activity of the influenza virus, according to the instructions of the Neuraminidase Inhibitors Screen Kit (Beyotime, China). Inhibition $=\left[(C-S) /\left(C-C_{0}\right)\right] \times 100 \%$, where $C$ is the fluorescence of the control (enzyme, buffer, and substrate) after $30 \mathrm{~min}$ of incubation, and $C_{0}$ is the fluorescence of the control (buffer and substrate). $S$ is the fluorescence of the tested samples (enzyme, sample solution, and substrate) after incubation. Standard curves were made by plotting the percentage of fluorescence inhibition relative to the activity of virus controls against the $\log _{2}$ of concentrations. In addition, $10 \mu \mathrm{g} / \mathrm{mL}$ oseltamivir phosphate was used as the positive control. Then, $10 \mu \mathrm{L}$ of NA in $70 \mu \mathrm{L}$ of reaction buffer was mixed with equal volumes of twofold dilutions of the compounds. After a 2-min incubation at $37{ }^{\circ} \mathrm{C}$, equal volumes $(10 \mu \mathrm{L})$ of the substrate solution [2-(4-methylumbelliferyl)- $\alpha-\mathrm{D}-N$-acetylneuraminic acid sodium (4-MU-NANA)] were added, and the mixtures were further incubated for $30 \mathrm{~min}$ at $37{ }^{\circ} \mathrm{C}$. The fluorescence intensity was measured using a fluorescence plate reader at an excitation wavelength of $322 \mathrm{~nm}$ and an emission wavelength of $450 \mathrm{~nm}$. The $50 \%$ inhibitory concentration $\left(\mathrm{IC}_{50}\right)$ was calculated by regression analysis with $r^{2} \geq 0.9$, representing the mean values of three independent experiments [13,29].

\section{Evaluation of the expression levels of matrix protein mRNA of the influenza virus using quantitative real-time polymerase chain reaction (RT-PCR)}

The expression level of matrix protein mRNA of the influenza virus was determined by reverse transcription and quantitative RT-PCR to evaluate the effects of each compound on virus replication. MDCK cells were grown to approximately $90 \%$ confluence in 24 well plates with $4 \times 10^{5}$ cells per well at $37{ }^{\circ} \mathrm{C}$ under 
Table 1 Chemical structures of phenanthrenes from the tuber of Bletilla striata

Structure

1

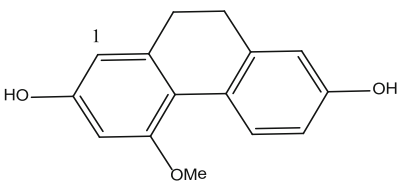

2
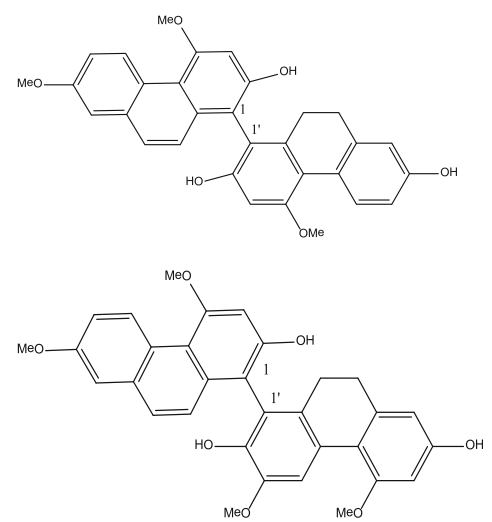

4

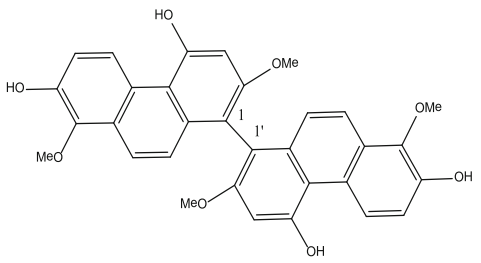

5

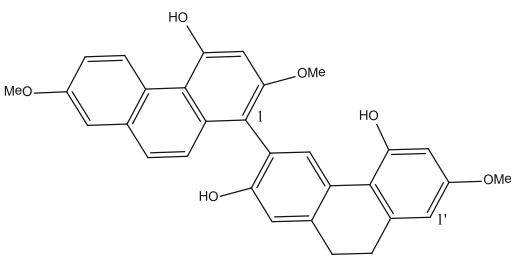

6
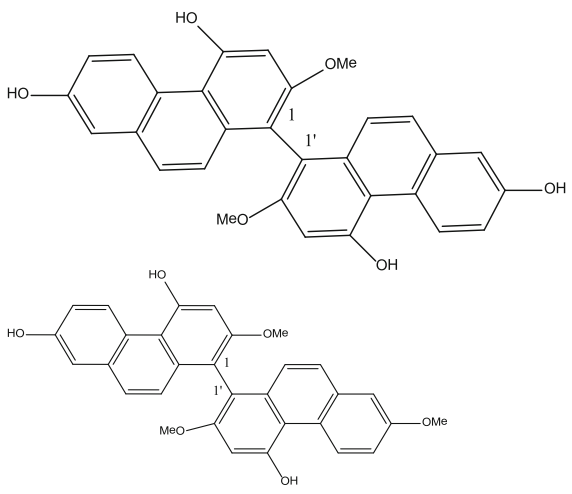

8

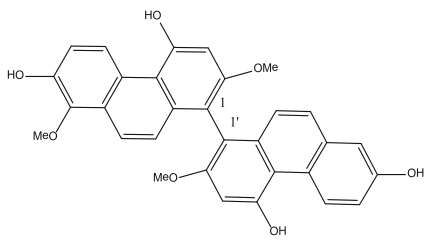

\section{Name}

2,7-dyhydroxyl-4-methoxy-9,10-dihydro-phenanthrene

2,2,7'-trihydroxy-4,4',7-trimethoxy-9',10'-dihydro-1,1'-diphenanthrene

2,2',7'-trihydroxy-3',4,5',7-tetramethoxy-9',10'-dihydro-1,1'-di-phenanthrene

4,4',7,7'-tetrahydroxy-2,2',8,8'-tetramethoxy-1,1'-di-phenanthrene

4,4',7'-trihydroxy-2,2',8,-trimethoxy-1,1'-di-phenanthrene

$4,4^{\prime}, 7,7^{\prime}$-tetrahydroxy-2,2'-dimethoxy-1,1'-di-phenanthrene

4,4',7-trihydroxy-2,2',7'-trimethoxy-1,1'-di-phenanthrene

4,4',7,7'-tetrahydroxy-2,2',8-trimethoxy-1,1'-di-phenanthrene 
Table 1 Chemical structures of phenanthrenes from the tuber of Bletilla striata (Continued)

9

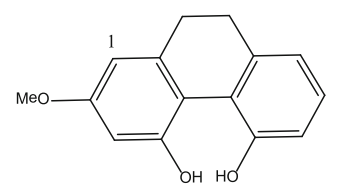

10

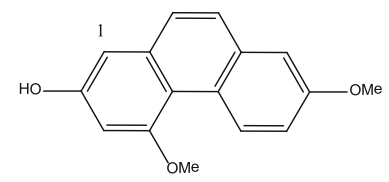

11

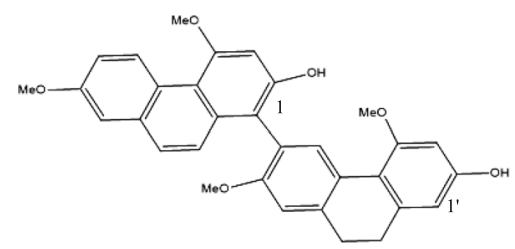

12

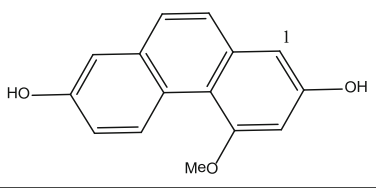

4,5-dyhydroxyl-2-methoxy-9,10-dihydro-phenanthrene

2-hydroxyl-4,7-dimethoxyphenanthrene

2,2'-dyhydroxyl-4,4',7,7'-9',10'-dihydro-1,6'-di-phenanthrene

2,7-dyhydroxyl-4-methoxyphenanthrene
$5 \% \mathrm{CO}_{2}$, infected with the influenza virus at 100 $\mathrm{TCID}_{50}$, and cultured in the presence of the compounds at a concentration of $8 \mu \mathrm{M}$. PBS and the virus without treatment were used as controls, and the positive control was oseltamivir phosphate. The medium was removed after $18 \mathrm{~h}$. The cells were scraped off, washed twice with PBS, and collected by centrifugation $(500 \times g$ for $3 \mathrm{~min})$. Total RNA was isolated using an RNeasy Mini Kit (Qiagen, Germany) according to the manufacturer's instructions. RT-PCR was performed using a One-Step PrimeScript RT-PCR Kit (TaKaRa Biotech, Dalian, China). The primer sequences used for quantitative real-time PCR of viral matrix protein mRNA were $5^{\prime}$-GAC CRA TCC TGT CAC CTC TGA C-3' (sense) and 5'-AGG GCA TTY TGG ACA AAK CGT CTA-3' (antisense) [30]. Glyceraldehyde 3-phosphate dehydrogenase (GAPDH) was used as an internal control of cellular RNAs, with primer sequences of $5^{\prime}$-CAA CGG ATT TGG CCG TAT TGG-3' (sense) and reverse: 5' -TGA AGG GGT CAT TGA TGG CG-3' (antisense) [11]. RT-PCR was conducted in a $25-\mu \mathrm{L}$ reaction system: $2 \times$ One-Step RT-PCR Buffer III, $12.5 \mu \mathrm{L}$; TaKaRa Ex Taq HS (5 U/ $\mu \mathrm{L}), 0.5 \mu \mathrm{L}$; PrimeScript RT Enzyme Mix II, $0.5 \mu \mathrm{L}$; PCR Forward Primer $(20 \mu \mathrm{M}) 0.6 \mu \mathrm{L}$; PCR Reverse Primer $(20 \mu \mathrm{M}), 0.6 \mu \mathrm{L}$; SYBR Green Dye, $1 \mu \mathrm{L}$; total RNA, $3 \mu \mathrm{L}$; and RNase-Free $\mathrm{dH}_{2} \mathrm{O}, 6.3 \mu \mathrm{L}$. The amplification conditions were as follows: $40{ }^{\circ} \mathrm{C}$ for $30 \mathrm{~min}$, $95{ }^{\circ} \mathrm{C}$ for $2 \mathrm{~min}, 95^{\circ} \mathrm{C}$ for $5 \mathrm{~s}$, and $55{ }^{\circ} \mathrm{C}$ for $35 \mathrm{~s}(40 \mathrm{cy}-$ cles). The data were analyzed using the mode for normalized expression $\left(2^{-\Delta \Delta C t}\right)$ [31].

\section{Statistical analysis}

Data was presented as mean \pm standard deviation (SD). Comparisons for all pairs were performed by the Student $t$ test using SPSS version 17.0 (SPSS, IL, USA). A $P$ value of $<0.05$ was considered to be significant. The $\mathrm{IC}_{50}$ and $\mathrm{CC}_{50}$ values were calculated using GraphPad Prism (GraphPad Software Inc., San Diego, CA, USA).

\section{Results}

We have isolated 12 phenanthrenes from the medicinal plant Bletilla striata. The structures and names of the phenanthrenes were listed (Table 1); the chromatogram (Fig. 2) and spectra (Additional file 1), as well as the spectral data for all the compounds (Additional file 1) were also provided. The compounds 1, 9, 10 and 12 have been reported before, while the compounds 2, 3, $4,5,6,7,8$ and 11 were new discoveries of our study.

\section{Antiviral activity in embryonated eggs}

The influenza virus A/Sydney/5/97 (H3N2) was propagated in 9-day-old chicken eggs; the dose was evaluated as $10^{7.8} \mathrm{EID}_{50} / \mathrm{mL}$. The suitable dilutions of all the compounds were set according to their solubility and toxicity. Then, 9-day-old swabbed eggs were inoculated with the compound-100 EID $_{50}$ virus mixture via the allantoic route at $34{ }^{\circ} \mathrm{C}$ for $48 \mathrm{~h}$. The virus titer of the allantoic fluid was measured by the hemagglutination test. The result showed that the $B$. striata compounds had significant antiviral activity against the influenza virus in the embryonated hen egg 


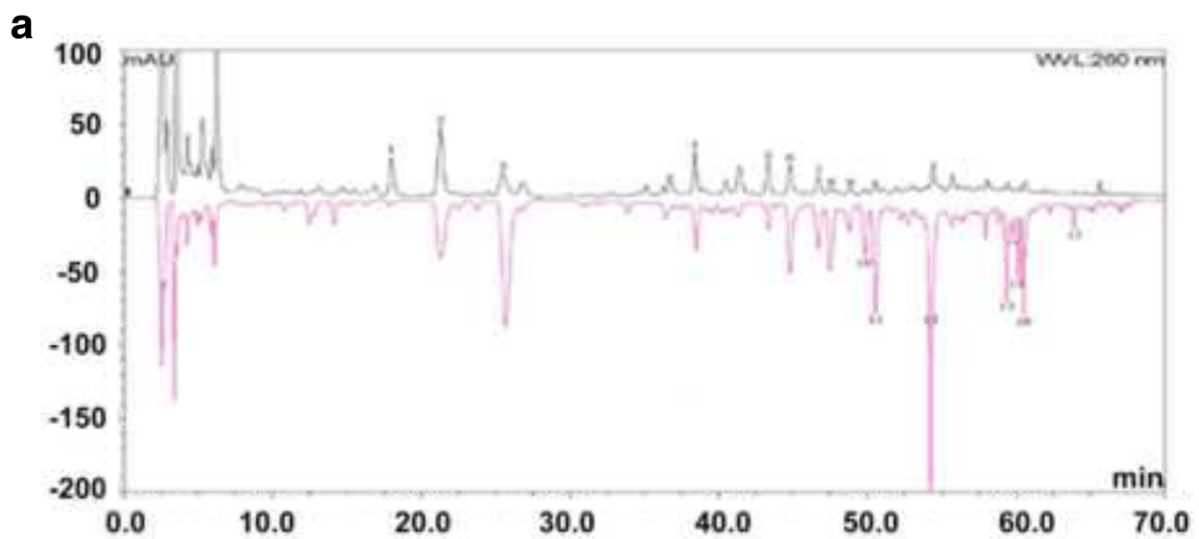

b

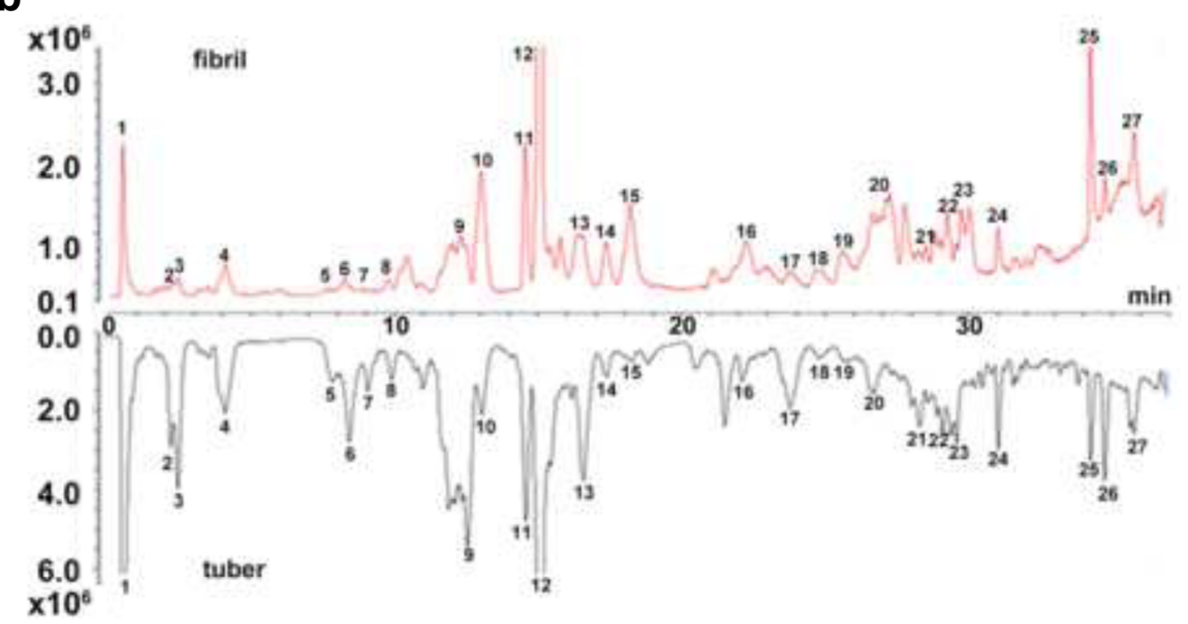

C

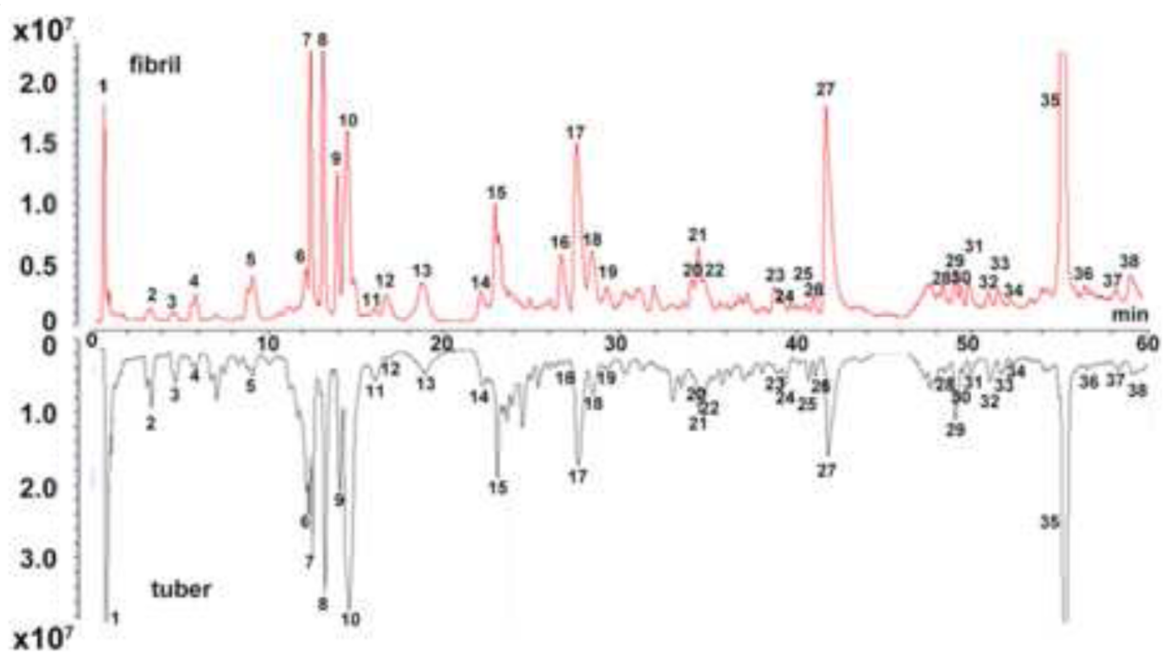

Fig. 2 Influenza virus-induced cytopathic effect. The five panels present different degrees of cytopathic effect in Madin-Darby canine kidney epithelial cells. $\mathbf{a}+; \mathbf{b}++; \mathbf{c}+++; \mathbf{d}++++; \mathbf{e}$ Normal control

model. Compared with the control, nine compounds could significantly decrease the titers of viruses, with inhibition rates of $20.7 \%$ (compound 1), $79.3 \%$ (compound 2), $17.2 \%$ (compound 3 ), 34.5\% (compound 4),
34.5\% (compound 6), 34.5\% (compound 9), 44.8\% (compound 10), 75.9\% (compound 11), and $34.5 \%$ (compound 12), at a concentration of $0.08 \mathrm{mmol} / \mathrm{egg}$ (Table 2). Compounds 2 and 11 were the best, 
Table 2 Antiviral activity of the compounds from Bletilla striata in embryonated hen eggs

\begin{tabular}{|c|c|c|c|}
\hline Compounds & Concentration (mmol/egg) & -log2 HA titer (mean \pm SD) & Inhibition (\%) \\
\hline \multirow[t]{3}{*}{1} & 0.08 & $4.60 \pm 0.55^{* *}$ & 20.69 \\
\hline & 0.16 & $2.20 \pm 0.45^{* *}$ & 62.07 \\
\hline & 0.32 & $0.40 \pm 0.55^{* *}$ & 93.10 \\
\hline \multirow[t]{3}{*}{2} & 0.02 & $5.80 \pm 0.84$ & 0.00 \\
\hline & 0.04 & $3.00 \pm 0.71^{* *}$ & 48.28 \\
\hline & 0.08 & $1.20 \pm 0.45^{* *}$ & 79.31 \\
\hline \multirow[t]{3}{*}{3} & 0.02 & $6.20 \pm 0.84$ & 0.00 \\
\hline & 0.04 & $5.40 \pm 0.55$ & 6.90 \\
\hline & 0.08 & $4.80 \pm 0.45^{* *}$ & 17.24 \\
\hline \multirow[t]{3}{*}{4} & 0.04 & $6.00 \pm 0.71$ & 0.00 \\
\hline & 0.08 & $3.80 \pm 0.84^{* *}$ & 34.48 \\
\hline & 0.16 & $0.00 \pm 0.00^{* *}$ & 100.00 \\
\hline \multirow[t]{3}{*}{5} & 0.02 & $5.80 \pm 0.84$ & 0.00 \\
\hline & 0.04 & $5.40 \pm 0.55$ & 6.90 \\
\hline & 0.08 & $5.60 \pm 0.55$ & 3.45 \\
\hline \multirow[t]{3}{*}{6} & 0.04 & $5.80 \pm 0.84$ & 0.00 \\
\hline & 0.08 & $3.80 \pm 0.84^{* *}$ & 34.48 \\
\hline & 0.16 & $0.00 \pm 0.00^{* *}$ & 100.00 \\
\hline \multirow[t]{3}{*}{7} & 0.02 & $6.80 \pm 0.45$ & 0.00 \\
\hline & 0.04 & $6.60 \pm 0.55$ & 0.00 \\
\hline & 0.08 & $6.40 \pm 0.55$ & 0.00 \\
\hline \multirow[t]{3}{*}{8} & 0.04 & $5.40 \pm 0.55$ & 6.90 \\
\hline & 0.08 & $2.20 \pm 0.45^{* *}$ & 62.07 \\
\hline & 0.16 & $0.40 \pm 0.55^{* *}$ & 93.10 \\
\hline \multirow[t]{3}{*}{9} & 0.04 & $6.00 \pm 0.71$ & 0.00 \\
\hline & 0.08 & $3.80 \pm 0.84^{* *}$ & 34.48 \\
\hline & 0.16 & $0.00 \pm 0.00^{* *}$ & 100.00 \\
\hline \multirow[t]{3}{*}{10} & 0.04 & $6.00 \pm 0.71$ & 0.00 \\
\hline & 0.08 & $3.20 \pm 0.40^{* *}$ & 44.83 \\
\hline & 0.16 & $0.60 \pm 0.49^{* *}$ & 89.66 \\
\hline \multirow[t]{4}{*}{11} & 0.02 & $6.40 \pm 0.55$ & 0.00 \\
\hline & 0.04 & $4.00 \pm 1.00^{* *}$ & 31.03 \\
\hline & 0.08 & $1.40 \pm 0.55^{* *}$ & 75.86 \\
\hline & 0.04 & $5.80 \pm 0.84$ & 0.00 \\
\hline \multirow[t]{2}{*}{12} & 0.08 & $3.80 \pm 0.84^{* *}$ & 34.48 \\
\hline & 0.16 & $0.60 \pm 0.55^{* *}$ & 89.66 \\
\hline \multirow[t]{3}{*}{ Oseltamivir } & 0.01 & $0.00 \pm 0.00^{* *}$ & 100.00 \\
\hline & Virus control & $5.80 \pm 0.84$ & / \\
\hline & Norm-control & $0.00 \pm 0.00$ & / \\
\hline
\end{tabular}

${ }^{*} P<0.01$ compared with the virus control; ${ }^{*} P<0.05$ compared with the virus control

although they seemed less efficient than oseltamivir, which showed a $100 \%$ inhibition rate at $0.01 \mathrm{mmol} /$ egg. The results for other concentrations are presented (Table 2).

\section{CPE reduction in MDCK cells}

In the first set of experiments, the cytotoxicity of the compounds was measured using the MTS-based assay. It was found that each compound reduced the viability 
of MDCK cells with the $\mathrm{CC}_{50}$ values (corresponding to a $50 \%$ cytotoxic effect after $48 \mathrm{~h}$ of the inhibitor treatment) lower than oseltamivir (Table 3). No morphological alternations, loss of cell viability, or modification of cell multiplication rates could be observed in the cells treated with B. striata compounds with selected working doses of each compound.

The MTS-based CPE reduction assay of the MDCK model was used to confirm the antiviral activity. The antiviral effect of the compounds was quantified using the selectivity index (SI), which was the ratio of $\mathrm{CC}_{50 \text { mean }}$ versus $\mathrm{IC}_{50 \text { mean }}$ values (Table 3 ). The data from the CPE reduction assay demonstrated that $B$. striata compounds exhibited inhibitory antiviral effects in two groups: simultaneous treatment and post-treatment. In the simultaneous treatment assay, compounds $2,3,4,6$, 7, 10, and 11 exhibited inhibitory activities against the influenza virus with $\mathrm{IC}_{50}$ values ranging from $14.6 \pm 2.4$ to $43.3 \pm 5.3 \mu \mathrm{M}$, and compound 4 showed the maximum inhibitory activity (Fig. 3 ). The $\mathrm{IC}_{50}$ values of $B$. striata compounds ranged from $18.4 \pm 3.1$ to $42.3 \pm 3.9 \mu \mathrm{M}$ in the post-treatment assay (Fig. 3). The compound 4 showed the most potent activity with the SI of 5.5, though it was lower than the value of oseltamivir at 122.2 .

\section{Hemagglutination inhibition of phenanthrenes from Bletilla striata}

The simultaneous treatment assay results indicated that treatment with $B$. striata compounds on virus entry

Table 3 Antiviral activities of phenanthrenes from Bletilla striata in MDCK cells

\begin{tabular}{|c|c|c|c|c|c|}
\hline \multirow[t]{2}{*}{ Compound } & \multirow{2}{*}{$\frac{C C 50}{(\mu M)^{a}}$} & \multicolumn{2}{|c|}{ Simultaneous treatment } & \multicolumn{2}{|c|}{ Post-treatment } \\
\hline & & $\mathrm{IC} 50(\mu \mathrm{M})^{\mathrm{b}}$ & $\mathrm{SI}^{\mathrm{C}}$ & $\mathrm{IC} 50(\mu \mathrm{M})^{\mathrm{b}}$ & $\mathrm{Sl} \mathrm{C}^{\mathrm{C}}$ \\
\hline 1 & $200.8 \pm 18.6$ & - & - & - & - \\
\hline 2 & $67.9 \pm 13.1$ & $28.6 \pm 4.3$ & 2.3 & $31.4 \pm 2.1$ & 2.2 \\
\hline 3 & $50.3 \pm 6.2$ & $20.4 \pm 3.2$ & 2.5 & $22.6 \pm 1.8$ & 2.2 \\
\hline 4 & $80.0 \pm 20.1$ & $14.6 \pm 2.4$ & 5.5 & $18.4 \pm 3.1$ & 4.3 \\
\hline 5 & $96.8 \pm 15.6$ & - & - & - & - \\
\hline 6 & $106.4 \pm 21.2$ & $33.8 \pm 2.7$ & 3.1 & $37.3 \pm 3.2$ & 2.8 \\
\hline 7 & $129.5 \pm 15.6$ & $28.5 \pm 2.8$ & 4.5 & $31.2 \pm 2.2$ & 4.1 \\
\hline 8 & $110.6 \pm 17.3$ & - & - & - & - \\
\hline 9 & $160.3 \pm 20.4$ & - & - & - & - \\
\hline 10 & $141.6 \pm 25.0$ & $43.3 \pm 5.3$ & 3.3 & $42.3 \pm 3.9$ & 3.4 \\
\hline 11 & $118.6 \pm 19.6$ & $38.6 \pm 2.9$ & 3.1 & $35.2 \pm 3.7$ & 3.4 \\
\hline 12 & $115.7 \pm 16.8$ & - & - & - & - \\
\hline Oseltamivir & $598.8 \pm 62.1$ & $4.9 \pm 0.9$ & 122.2 & $0.9 \pm 0.2$ & 665.3 \\
\hline
\end{tabular}

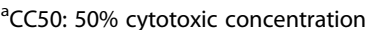

bIC50: 50\% inhibitory concentration

'SI: selective index; CC50mean/IC50mean

-: The results showed that antiviral effects against $A / S y d n e y / 5 / 97(H 3 N 2)$ were less than $50 \%$ inhibition abrogated virus infectivity. Hence, the hemagglutination inhibition assay was used to test the hypothesis that $B$. striata compounds interfere with viral attachment. However, the results showed that the compounds could not inhibit hemagglutination by the influenza virus, neither do oseltamivir (Fig. 4).

\section{Neuraminidase inhibition of phenanthrenes from Bletilla striata}

The NA activity assay (NA standard curve and the detailed data are shown in Additional file 1, Fig. 5 and Table 4) was performed to detect any antiviral effect of $B$. striata compounds and to determine the mechanisms. The results (Table 5) showed that compounds 1 , $3,4,6,10$, and 11 exhibited an inhibitory effect on the NAs in a dose-dependent manner with $\mathrm{IC}_{50}$ values ranging from $16.8 \pm 1.6$ to $87.5 \pm 10.1 \mu \mathrm{M}$. Compounds 3 , 4 , and 6 displayed a higher inhibitory activity against the NAs. As a known NA inhibitor, oseltamivir showed a much lower $\mathrm{IC}_{50}$ of $0.3 \pm 0.02 \mu \mathrm{M}$.

\section{Inhibition of viral RNA synthesis in MDCK cells}

The synthesis of influenza viral matrix protein mRNA was compared between untreated infected cells and infected cells treated with the compounds to identify any inhibitory effect of the compounds on influenza virus replication. RNA extraction was performed $18 \mathrm{~h}$ after influenza virus infection, and the levels of intracellular influenza RNA were measured. Quantitative RT-PCR showed a reduction in matrix protein mRNA transcription in cell treated with the $B$. striata compounds $(8 \mu \mathrm{M})$ compared with the untreated infected cells (Fig. 6). Compounds 1, 2, 3, 4, 6, 7, 9, 10, and 11 showed a stronger inhibitory effect, with the compound 4 most efficient, even more powerful than oseltamivir. These results indicated that the blockage of virus replication was one of the mechanisms by which $B$. striata compounds exerted antiviral effects.

\section{Discussion}

Influenza remains a serious problem in many countries, with a long history of outbreaks, epidemics, and recent pandemic [1-4]. With developments in viral biology, more novel antiviral strategies targeting these viruses, such as HA, M2 ion channel protein, RNAdependent RNA polymerase (RdRp), NP, NS, and NA, have been developed. The two main classes of antiviral drugs clinically used against influenza are inhibitors of the viral M2 protein, such as amantadine (Symmetrel) and rimantadine (Flumadine), or neuraminidase inhibitors, such as zanamivir (Relenza) and oseltamivir (Tamiflu) (Fig.7).

M2 protein inhibitor amantadine consists of an adamantane backbone that has an amino group substituted 


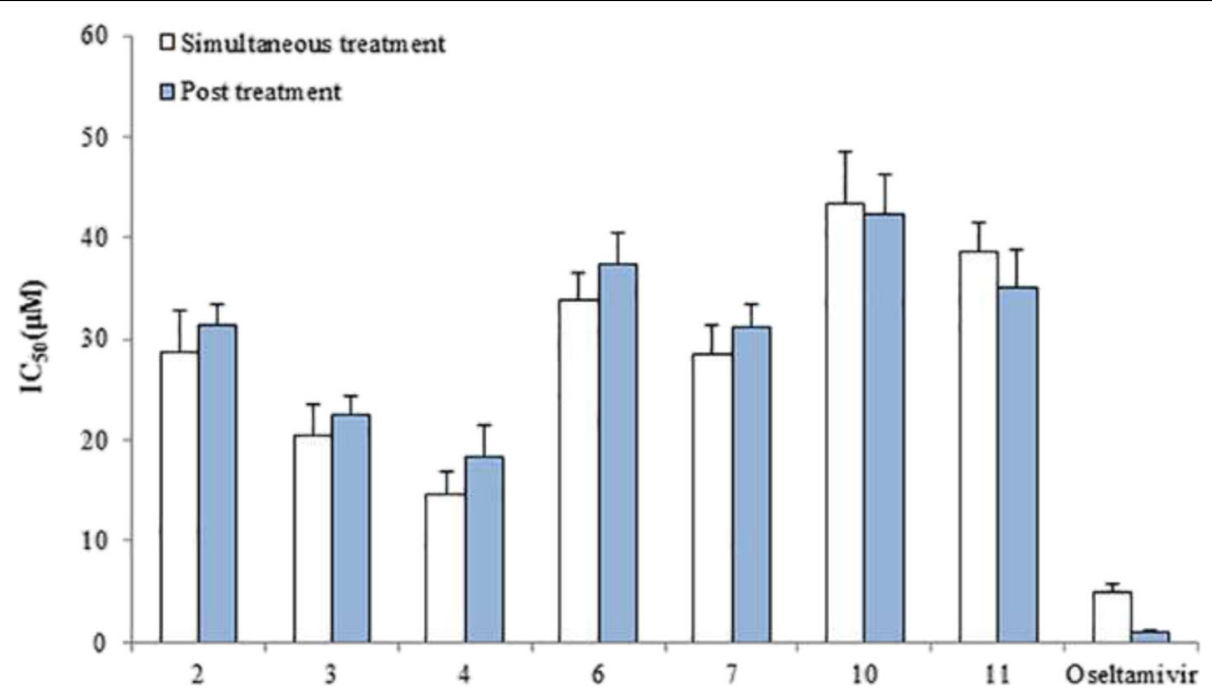

Fig. 3 Determination of the $I_{50}$ of phenanthrenes from Bletilla striata by the cytopathic effect (CPE) reduction assay in Madin-Darby canine kidney epithelial cells.. *No significant difference between the two treatments

at one of the four methyne positions, and rimantadine is a closely related derivative of adamantane with similar biological properties (Fig. 8). According to the US Centers for Disease Control and Prevention, 100\% of seasonal H3N2 and 2009 pandemic flu samples tested have shown resistance to adamantanes, and amantadine is no longer recommended for the treatment of influenza in the United States. A new M2 protein inhibitor is urgently needed.
The M2 channel transports protons from the vacuolar space into the interior of the virion. Acidification of the interior results in the dissociation of ribonucleoproteins and the onset of viral replication. Amantadine and rimantadine function in a mechanistically identical fashion in entering the barrel of the tetrameric M2 channel and blocking the pore function (i.e., proton translocation) [32, 33]. Resistance to the drug class is a consequence of mutations to the pore-lining residues of the channel, leading to
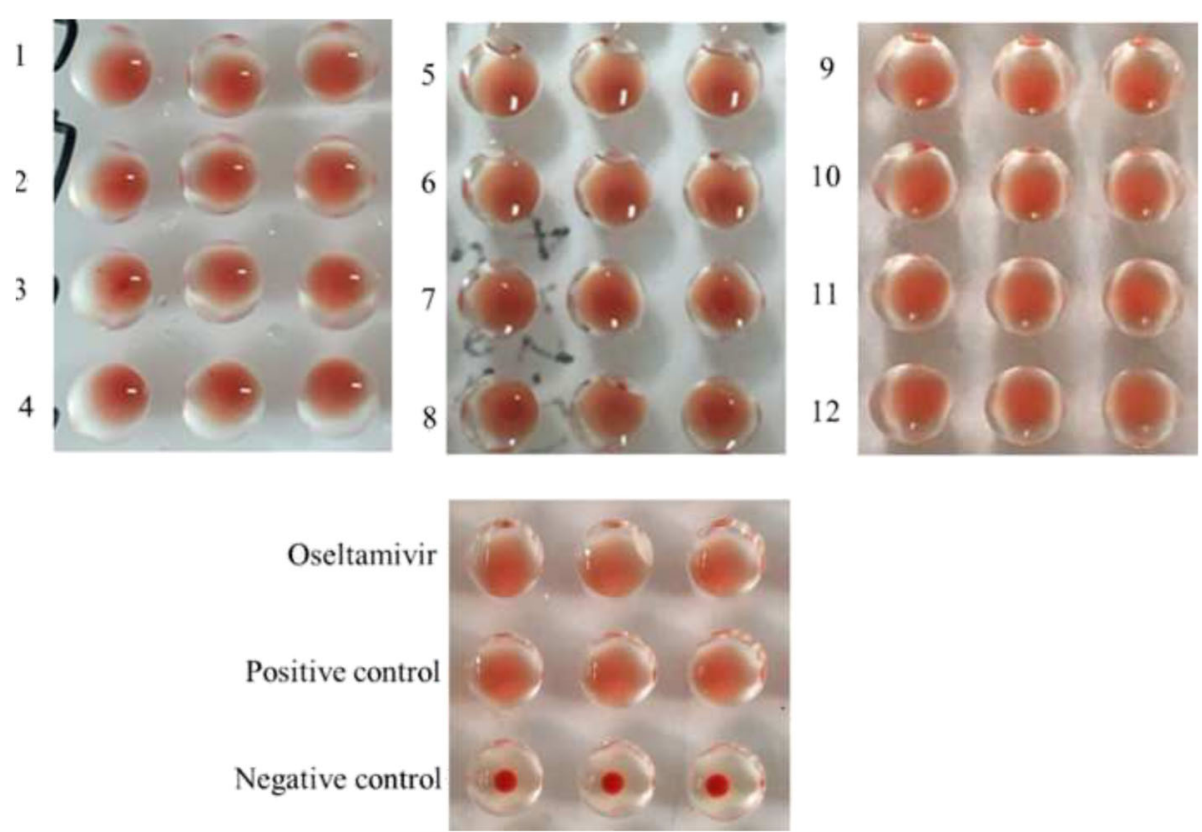

Fig. 4 Hemagglutination inhibition of phenanthrenes from Bletilla striata. The hemagglutination inhibition assay was used to test the hypothesis that $B$. striata compounds interfere with viral attachment. However, the results showed that the compounds could not inhibit hemagglutination by the influenza virus 


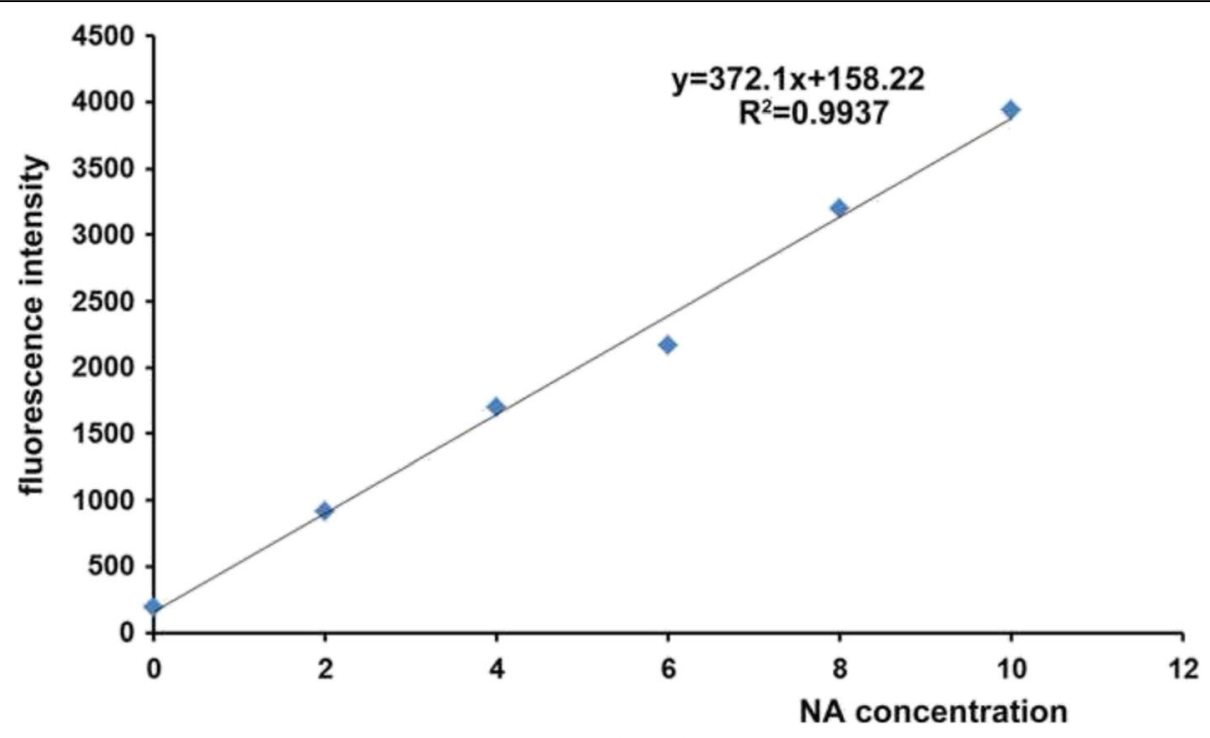

Fig. 5 Neuraminidase standard curve performed to detect any antiviral effect of B. striata compounds

the inability of the sterically bulky adamantane ring that both share in entering in their usual way into the channel.

Neuraminidase inhibitor serves as a competitive inhibitor of the activity of the viral neuraminidase (NA) enzyme on SA found in glycoproteins on the surface of normal host cells. By blocking the activity of the enzyme, oseltamivir prevents new viral particles from being released through the cleaving of terminal SA on glycosylated hemagglutinin (Fig. 7, Wikipedia). The discovery of the first designed influenza virus neuraminidase inhibitor and anti-influenza drugs zanamivir and, subsequently, oseltamivir has now inspired a number of continuing efforts toward the discovery of nextgeneration anti-influenza drugs [34].

Phenanthrene is a polycyclic aromatic hydrocarbon composed of three fused benzene rings. The name "phenanthrene" is a composite of phenyl and anthracene. Most natural phenanthrenes originate biosynthetically from stilbenoids via oxidative coupling of the aromatic rings. They have demonstrated a variety of pharmacological effects, such as antiallergic, anti-inflammatory, antimicrobial, cytotoxic, and spasmolytic activities. Further C-C

Table 4 NATA for NA standard curve

\begin{tabular}{llllll}
\hline \multirow{2}{*}{$\begin{array}{l}\text { NA } \\
(\mathrm{ng} / \mathrm{mL})\end{array}$} & \multicolumn{3}{l}{ Fluorescence intensity } & SD \\
\cline { 2 - 5 } & 1 & 2 & 3 & mean & \\
\hline 0 & 185.2 & 192.2 & 193.7 & 190.4 & 4.5 \\
2 & 982.0 & 826.0 & 942.0 & 916.7 & 81.0 \\
4 & 1734.0 & 1780.0 & 1592.0 & 1702.0 & 98.0 \\
6 & 2190.0 & 2190.0 & 2121.0 & 2167.0 & 39.8 \\
8 & 3304.0 & 3201.0 & .091 .0 & 3198.7 & 106.5 \\
10 & 3961.3 & 3892.5 & 3958.9 & 3937.6 & 39.0 \\
\hline
\end{tabular}

coupling of two phenanthrenes by $1-1^{\prime}, 1-3^{\prime}, 1-8^{\prime}$, or $3-3$ ' linkages produces rarely occurring biphenanthrenes, which show interesting atropisomeric features due to the hindered rotation of the linkage bond when $-\mathrm{OH}$ or -OMe groups are present nearby. Some synthetic chiral biphenanthrenes have been applied as effective enantioselective catalysts and ligands, while the atropisomeric features of many natural biphenanthrenes are not always discussed fully in scientific publications. The optically active naturally occurring biphenanthrene blestriarene $\mathrm{C}$ was shown to undergo rapid racemization even in daylight $[35,36]$.

Some compounds used to fight viral infections are based on the phenanthrene core, including compounds

Table 5 NA inhibitory activity of phenanthrenes from Bletilla striata

\begin{tabular}{ll}
\hline Compound & IC50 $(\mu \mathrm{M})$ \\
\hline 1 & $72.6 \pm 6.5$ \\
2 & - \\
3 & $16.8 \pm 1.6$ \\
4 & $21.7 \pm 2.9$ \\
5 & - \\
6 & $16.1 \pm 2.6$ \\
7 & - \\
8 & - \\
9 & - \\
10 & $87.5 \pm 10.1$ \\
11 & $57.6 \pm 5.9$ \\
12 & - \\
Oseltamivir & $0.3 \pm 0.02$ \\
\hline$-:$ Inhibitory effect on the NA was less than $50 \%$. &
\end{tabular}




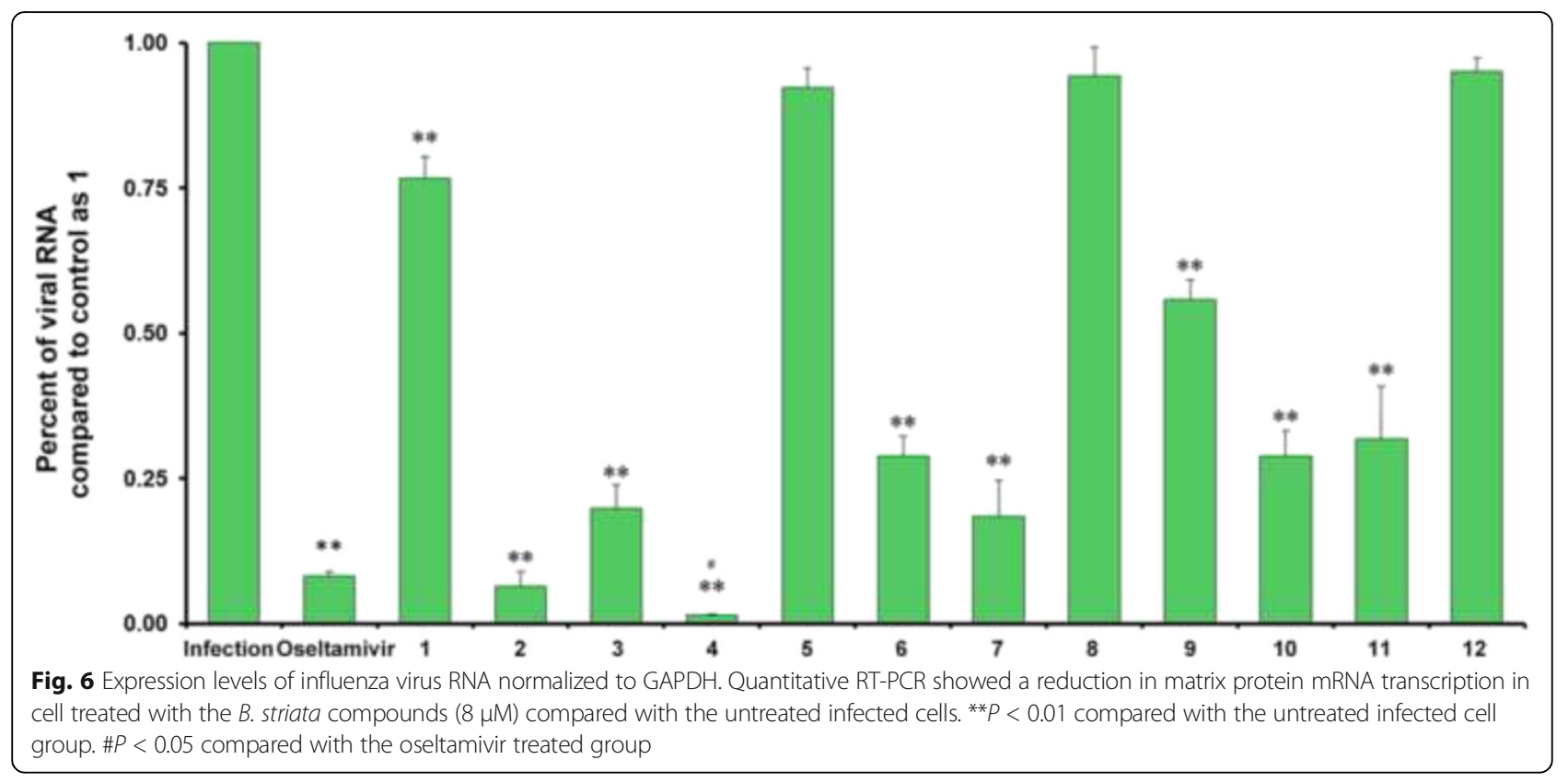

against plant viruses [37, 38] and human viruses [39, 40]. The secretion of phenanthrenes is a natural defense mechanisms of plants against fungal infection [40]. Phenanthrenes from B. striata have some efficacy against Gram-positive bacteria, but only weak efficace against fungi [41]. The phenanthrenes of Taxol communis have some efficacy against the vesicular stomatitis virus and the human rhinovirus serotype 1B [39]. A phenanthrene derivative showed some efficacy against coronaviruses [42]. The antiviral property of phenanthrenes from $B$. striata against the influenza A virus was investigated in this study using embryonated hen eggs, and it was confirmed that compounds 1, 2, 3, $4,6,9,10,11$, and 12 exerted significant inhibitory effects. In MDCK models, compounds 2, 3, 4, 6, 7, 10, and 11 exhibited CPE reduction activities. The study showed that phenanthrenes from $B$. striata had strong anti-influenza viral activity. Furthermore, the HA, matrix protein, and NA were employed as targets for the study of possible mechanisms.
B. striata compounds 2, 3, 4 6, 7, 10, and 11 served as matrix protein inhibitors and resulted in the reduction of mRNA transcription. The function-structure relationship of these compounds and whether they interfere with the M2 proton channel need further exploration.

Compounds $1,3,4,6,10$, and 11 exhibited an inhibitory effect on NA; compounds 3, 4, and 6 displayed a higher inhibitory activity. NA is an exoglycosidase that destroys the HA receptor by cleaving the $\alpha(2,6)$ - or $\alpha(2,3)$-ketosidic linkage that exists between a terminal SA and a sugar residue of the $\mathrm{N}$ acetylneuraminic acid (Neu5Ac)-containing receptor on the surface of the host cells [5]. Neuraminidase inhibitors commonly interfere with the enzyme activity by mimicking the natural substrate and fitting into the active site of the neuraminidase enzyme. The binding efficiency of the compound with the neuraminidase is the major determinant of the inhibitory activity. The structure-activity relationship of new neuraminidase inhibitors should be proved for better molecular<smiles>CCOC(=O)C1=C[C@@H](OC(CC)CC)[C@H](NC(C)=O)[C@H](N)C1</smiles> 
The action of neuraminidase in replication of virions in influenza infection.

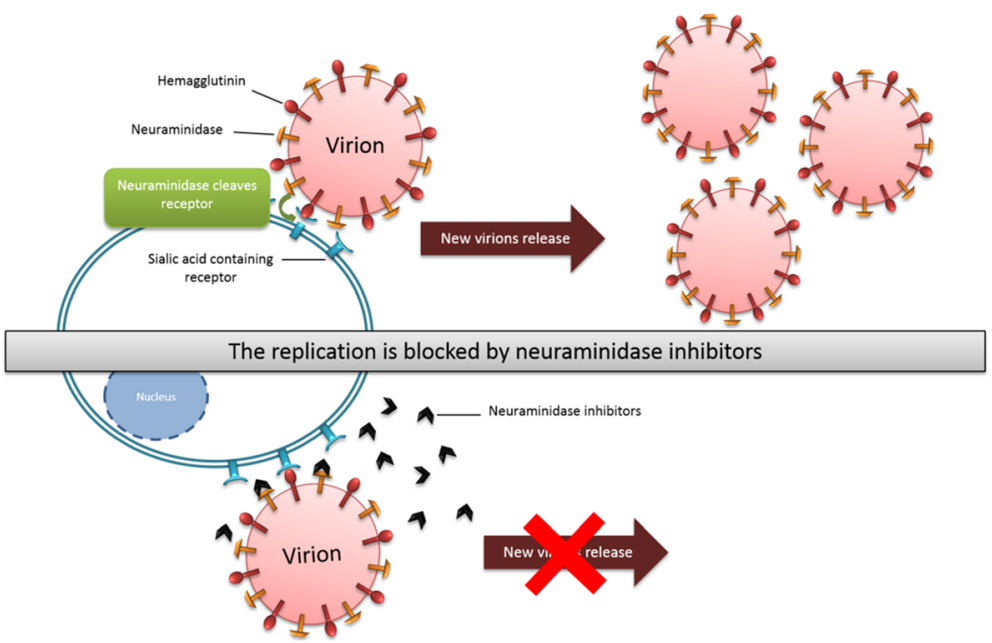

Fig. 8 Mechanism of action of neuraminidase inhibitors

properties and higher efficiency against neuraminidase receptor compared with zanamivir or oseltamivir.

In the present study, compounds 4, 6, 9, and 12 showed the same efficacy in the egg model. The reasons for the similar efficacy are presently unknown. Indeed, these four compounds do not share the same molecular structure. The results could have been biased by the small number of eggs used in the experiments. There is also a possibility that these compounds share a mechanism that has not been studied here. In addition, some compounds inhibited the influenza virus through two mechanisms, but the reasons for this dual inhibition are currently unknown. Additional studies are necessary to better characterize these compounds.

\section{Conclusions}

This study indicated that diphenanthrenes (compounds 2-8 and 11) had stronger inhibitory activity compared with monophenanthrenes (compounds 1, 9, 10, and 12). In MDCK models, the antiviral effects of most monophenanthrenes were less than $50 \%$ except compound 10, while the effects of diphenanthrenes were all higher than $50 \%$ and $\mathrm{IC}_{50}$ could be calculated. This might be because of the hydroxyl group, which impacts the hydrophilicity/hydrophobicity of the compound. All diphenanthrenes share more hydroxyl groups. However, how the hydroxyl group affects the antiviral activity still needs further investigation. Compounds $2,3,4,6,7,10$, and 11 served as matrix protein inhibitors and resulted in the reduction of mRNA transcription. Compounds 1, $3,4,6,10$, and 11 exhibited an inhibitory effect on
NA. Additional studies are required to elucidate the exact mechanisms of these compounds.

\section{Additional file}

Additional file 1: The additional file are data of virus HA titer of allantoic fluid from embryonated hen eggs to assay antiviral activity and data for NA standard curve. (DOCX $2775 \mathrm{~kb}$ )

\section{Abbreviations}

CPE: Cytopathic effect; DPPH: Diphenyl-1-picrylhydrazyl; FBS: Fetal bovine serum; HA: Hemagglutinin; HAU: Hemagglutination units; HPLC: Highperformance liquid chromatography; MDCK: Madin-Darby canine kidney; MEM: Minimum essential medium; NA: Neuraminidase; NPs: Nucleoproteins; PBS: Phosphate-buffered saline; RBC: Red blood cells; RdRp: RNA-dependent RNA polymerase

\section{Acknowledgments}

We thank Professor Jie Yan at Zhejiang University School of Medicine for help in designing the hemagglutination inhibition assay. We also express our gratitude to Fusheng Jiang and Yong Shen at Zhejiang Chinese Medical University for help in spectroscopic analysis of compounds.

\section{Author's contributions}

YS and BZ carried out the studies, participated in collecting data, and drafted the manuscript. YL, CQ and LF performed the statistical analysis and participated in its design. YF, DC and ZD helped to draft the manuscript. All authors read and approved the final manuscript.

\section{Funding}

The research was supported by the Science and Technology plan of Zhejiang Province (No. 782213E00901).

\section{Availability of data and materials}

The datasets analysed during the current study will not be publicly available to protect patient confidentiality.

\section{Competing interests}

The authors declare that they have no competing interest.

Consent for publication

Not applicable. 


\section{Ethics approval and consent to participate}

Not applicable.

\section{Publisher's Note}

Springer Nature remains neutral with regard to jurisdictional claims in published maps and institutional affiliations.

\section{Author details}

'College of Medical Technology, Zhejiang Chinese Medical University, Hangzhou, Zhejiang 310053, China. ${ }^{2}$ Zhejiang Provice Center For Disease Control and Prevention, Hangzhou, Zhejiang 310051, China. ${ }^{3}$ College of Life Science, Zhejiang Chinese Medical University, Hangzhou, Zhejiang 310053, China. ${ }^{4}$ Department of Biological Sciences, University of

Wisconsin-Milwaukee, Milwaukee 53211, USA.

Received: 16 January 2017 Accepted: 8 May 2017

Published online: 22 May 2017

\section{References}

1. Rambaut A, Pybus OG, Nelson MI, Viboud C, Taubenberger JK, Holmes EC The genomic and epidemiological dynamics of human influenza A virus. Nature. 2008:453:615-9.

2. Korteweg C, Gu J. Pandemic influenza A (H1N1) virus infection and avian influenza A (H5N1) virus infection: a comparative analysis. Biochem Cell Biol. 2010;88:575-87.

3. Krammer F, Palese P. Advances in the development of influenza virus vaccines. Nat Rev Drug Discov. 2015;14:167-82.

4. Reperant LA, Grenfell BT, Osterhaus AD. Quantifying the risk of pandemic influenza virus evolution by mutation and re-assortment. Vaccine. 2015;33: 6955-66.

5. Foll M, Poh YP, Renzette N, Ferrer-Admetlla A, Bank C, Shim H, et al. Influenza virus drug resistance: a time-sampled population genetics perspective. PLoS Genet. 2014;10:e1004185.

6. Hurt AC. The epidemiology and spread of drug resistant human influenza viruses. Curr Opin Virol. 2014;8:22-9.

7. Edinger TO, Pohl MO, Stertz S. Entry of influenza A virus: host factors and antiviral targets. J Gen Virol. 2014:95:263-77.

8. Gong J, Fang H, Li M, Liu Y, Yang K, Liu Y, et al. Potential targets and their relevant inhibitors in anti-influenza fields. Curr Med Chem. 2009:16:3716-39.

9. Ni F, Chen X, Shen J, Wang Q. Structural insights into the membrane fusion mechanism mediated by influenza virus hemagglutinin. Biochemistry. 2014; 53:846-54.

10. Patil D, Roy S, Dahake R, Rajopadhye S, Kothari S, Deshmukh R, et al. Evaluation of Jatropha curcas Linn. leaf extracts for its cytotoxicity and potential to inhibit hemagglutinin protein of influenza virus. Indian J Virol. 2013;24:220-6.

11. Kwon HJ, Kim HH, Yoon SY, Ryu YB, Chang JS, Cho KO, et al. In vitro inhibitory activity of Alpinia katsumadai extracts against influenza virus infection and hemagglutination. Virol J. 2010;7:307.

12. Gong J, Xu W, Zhang J. Structure and functions of influenza virus neuraminidase. Curr Med Chem. 2007;14:113-22.

13. Aoki Y, Tanimoto S, Takahashi D, Toshima K. Photodegradation and inhibition of drug-resistant influenza virus neuraminidase using anthraquinone-sialic acid hybrids. Chem Commun (Camb). 2013;49:1169-71.

14. Yang JR, Huang YP, Lin YC, Su CH, Kuo CY, Hsu LC, et al. Early findings of oseltamivir-resistant pandemic (H1N1) 2009 influenza A viruses in Taiwan. Antivir Res. 2010:88:256-62

15. de Jong MD, Tran TT, Truong HK, Vo MH, Smith GJ, Nguyen VC, et al. Oseltamivir resistance during treatment of influenza A (H5N1) infection. N Engl J Med. 2005;353:2667-72.

16. Feng JQ, Zhang RJ, Zhao WM. Novel Bibenzyl Derivatives from the Tubers of Bletilla striata. Helv Chim Acta. 2008;91:520-5.

17. Bai L, Kato T, Inoue K, Yamaki M, Takagi S. Blestrianol A, B and C, biphenanthrenes from Bletilla striata. Phytochemistry. 1991;30:2733-5.

18. Yamaki M, Bai L, Kato T, Inou K, Takagi S, Yamagataa Y. Bisphenanthrene ethers from Bletilla striata. Phytochemistry. 1992;31:3985-7.

19. Yamaki M, Kato T, Li B, Inoue K, Takagi S. Phenanthrene glucosides from Bletilla striata. Phytochemistry. 1993:34:535-7.

20. Dong J, Lu M, Zhou H, Zhang W, Li Y, Dong W. Clinical analysis of primary nasal sinus osteoma. Zhonghua Er Bi Yan Hou Tou Jing Wai Ke Za Zhi. 2015; 50:8-13.
21. Kubo M, Sato N, Yamazaki M, Matsuda H. Application studies of Bletillae Rhizoma (Rhizomes of Bletilla striata) on Atopic Dermatitis. Nat Med. 2003; 57:55-60.

22. Jiang F, Li W, Huang Y, Chen Y, Jin B, Chen N, et al. Antioxidant, antityrosinase and antitumor activity comparison: the potential utilization of fibrous root part of Bletilla striata (Thunb.) Reichb.f. PLoS One. 2013;8: e58004

23. Qian CD, Jiang FS, Yu HS, Shen Y, Fu YH, Cheng DQ, et al. Antibacterial Biphenanthrenes from the Fibrous Roots of Bletilla striata. J Nat Prod. 2015; 78:939-43.

24. Wang JX, Zhou JY, Yang QW, Chen Y, Li X, Piao YA, et al. An improved embryonated chicken egg model for the evaluation of antiviral drugs against influenza A virus. J Virol Methods. 2008;153:218-22.

25. Sauerbrei A, Haertl A, Brandstaedt A, Schmidtke M, Wutzler P. Utilization of the embryonated egg for in vivo evaluation of the anti-influenza virus activity of neuraminidase inhibitors. Med Microbiol Immunol. 2006;195:65-71.

26. Reed $\mathrm{L}$, Muench $\mathrm{H}$. A simple method of estimating fifty percent endpoints. Am J Hyg. 1938;27:493-7.

27. Mantani N, Andoh T, Kawamata $H$, Terasawa $K$, Ochiai $H$. Inhibitory effect of Ephedrae herba, an oriental traditional medicine, on the growth of influenza A/PR/8 virus in MDCK cells. Antivir Res. 1999;44:193-200.

28. Ehrhardt C, Hrincius ER, Korte V, Mazur I, Droebner K, Poetter A, et al. A polyphenol rich plant extract, CYSTUS052, exerts anti influenza virus activity in cell culture without toxic side effects or the tendency to induce viral resistance. Antivir Res. 2007;76:38-47.

29. Thorlund K, Awad T, Boivin G, Thabane L. Systematic review of influenza resistance to the neuraminidase inhibitors. BMC Infect Dis. 2011;11:134.

30. Rajao DS, Couto DH, Gasparini MR, Costa ATR, Rein JKP, Lobato ZIP. Diagnosis and clinic-pathological findings of influenza virus infection in Brazilian pigs. Pesqui Vet Bras. 2013;33:30-6.

31. Zu M, Yang F, Zhou W, Liu A, Du G, Zheng L. In vitro anti-influenza virus and anti-inflammatory activities of theaflavin derivatives. Antivir Res. 2012; 94:217-24.

32. Wang C, Takeuchi K, Pinto LH, Lamb RA. Ion channel activity of influenza A virus M2 protein: characterization of the amantadine block. J Virol. 1993:67: 5585-94.

33. Jing $X$, Ma C, Ohigashi $Y$, Oliveira FA, Jardetzky TS, Pinto $L H$, et al. Functiona studies indicate amantadine binds to the pore of the influenza A virus M2 proton-selective ion channel. Proc Natl Acad Sci U S A. 2008;105:10967-72.

34. Bhakat S, Shaikh F, Yadav S. Identification of neuraminidase inhibitors by structure-based screening: promising new leads for influenza. Med Chem Res. 2014:23:2803-9.

35. Li $L$, Jiang $M$, Shen $X$. Variability in antioxidant/detoxification enzymes of Sinonovacula constricta exposed to benzo[a]pyrene and phenanthrene. Mar Pollut Bull. 2016;109:507-11.

36. Ma W, Zhang Y, Ding YY, Liu F, Li N. Cytotoxic and anti-inflammatory activities of phenanthrenes from the medullae of Juncus effusus L. Arch Pharm Res. 2016:39:154-60.

37. Wang K, Hu Y, Liu Y, Mi N, Fan Z, Liu Y, et al. Design, synthesis, and antiviral evaluation of phenanthrene-based tylophorine derivatives as potential antiviral agents. J Agric Food Chem. 2010;58:12337-42.

38. Yu X, Wei P, Wang Z, Liu Y, Wang L, Wang Q. Design, synthesis, antiviral activity and mode of action of phenanthrene-containing $\mathrm{N}$-heterocyclic compounds inspired by the phenanthroindolizidine alkaloid antofine. Pest Manag Sci. 2016:72:371-8.

39. Aquino R, Conti C, De Simone F, Orsi N, Pizza C, Stein ML. Antiviral activity of constituents of Tamus communis. J Chemother. 1991:3:305-9.

40. Kovacs A, Vasas A, Hohmann J. Natural phenanthrenes and their biological activity. Phytochemistry. 2008:69:1084-110.

41. Yamaki M, Bai L, Inoue K, Takagi S. Biphenanthrenes from Bletilla striata. Phytochemistry. 1989:28:3503-5.

42. Lin SY, Liu CL, Chang YM, Zhao J, Perlman S, Hou MH. Structural basis for the identification of the $\mathrm{N}$-terminal domain of coronavirus nucleocapsid protein as an antiviral target. J Med Chem. 2014;57:2247-57. 